\title{
DIGITAL REORIENTATION OF ISLAMIC HIGHER EDUCATION IN INDONESIA
}

\author{
Kastolani \\ State Islamic Institute of Salatiga \\ Salatiga, Central Java, Indonesia, 50721 \\ E-Mail:kastolani@iainsalatiga.ac.id
}

\begin{tabular}{c|c|c}
\hline Received: & Revised: & Approved: \\
22/05/2019 & $02 / 06 / 2019$ & $20 / 06 / 2019$ \\
\hline
\end{tabular}

DOI: http://dx.doi.org/10.32332/akademika.v24i1.1618

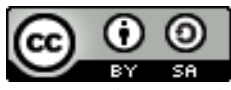

Digital Reorientation of Islamic Higher Education in Indonesia Licensed Under a Creative Commons Attribution-ShareAlike 4.0 International License

\begin{abstract}
The digital era and rapid technological developments require responses from various institutions to be able to survive and be able to use it well. Islamic education also needs to respond to this. Therefore, the reorientation of Islamic education in the digital era is important to discuss. This article aims to discuss various thoughts related to the reorientation of Islamic education in the digital era. The discussion is focused on approaches, models, and methods in Islamic studies at Islamic higher education using descriptive analysis. This article recommends the reorientation of Islamic education in the digital era can be done through three things, namely first, with a historical approach, second, by avoiding pseudo-diversification models, and third, by using Blended e-learning methods. Thus the Islamic Higher Education institutions can carry out its role and function in education that is sensitive to the times and at the same time the manifestation of Islam as rahmatanlil 'alamin in the digital era.
\end{abstract}

Keywords: Blended E-Learning, Digital Era, and Technology. 


\section{A. Introduction}

The rapid development of technology provides enormous benefits for humanity. The digital era requires digitization in various aspects of life. One of them, digitalization in the aspect of education becomes more effective and efficient in carrying out its role and function in educating the life of the nation. Indonesia's higher education policy response includes at least four main focuses. First, the need to align the paradigm. Secondly, the need to reorient the curriculum which can include new literacy such as big data, technology/coding, and humanities. Extracurricular activities in the form of leadership development and teamwork should be encouraged. Entrepreneurship and internships also need to be required. Third, it is necessary to apply blended/hybrid learning online. Fourth, the need for grants and technical guidance to reorient the curriculum 1 .

The digital era does not exclude the attention of Islamic education. As one of the concrete responses, the event was held at the 19th Annual International Conference on Islamic Studies (AICIS 2019) which carried the theme Digital Islam, Education, and Youth: Changing Landscape of Indonesian Islam. At the welcoming remarks, the Director of Diktis, Arskal Salim, said that the theme was aimed at looking more closely at how the relationship between Islam and the global world, especially on the shifting discourse from Islam as a social fact to the emerging digital landscape of Islam. This is an emerging situation and a strong field for research ${ }^{2}$.

In this regard, Amin Abdullah stated that the development of information technology and social networks brought along and caused the linearity of the field of science, especially the sciences in religion, posed a great risk in living in broader society, especially in public like today. Religion without sociology can shake and reduce one's position, dignity, and occupation. Natural science without sociology and anthropology can cause discomfort when side by side with other people of different religions. Conversely, anthropologists, sociologists, medicine who do not understand the matter of fiqh can provide unexpected risks.Individual piety reflected in ritual obedience does not necessarily form social or public piety. Academic discussions regarding the relationship between religion, science, and culture need to be continuously discussed, deepened and developed ${ }^{3}$.

${ }^{1}$ Hasnidar Burhan, "Era Digital, Kurikulum PT Dirombak," Nasional.Sindonews.Com, 2018.

2Arskal Salim, "Welcome to AICIS 2019 Digital Islam Education Youth," 2019, http://diktis.kemenag.go.id/aicis/index.php/home/.

${ }^{3} \mathrm{M}$ Amin Abdullah, "RELIGION, SCIENCE AND CULTURE An Integrated, Interconnected Paradigm of Science 1" 52, no. 1 (2014): 175-203, https://doi.org/10.14421/ajis.2014.521.175-203. 
Islamic higher education has an important role in this effort, one of which is through the reorientation of Islamic education.

Indonesia needs higher education institutions that do not only develop national culture but also function as the heart of a nation* ${ }^{4}$ Universities must be able to spur the development of independent workforce, have high work ethics, are professional, highly competitive, and responsive to technological changes ${ }^{5}$. Therefore, the reorientation of Islamic education in the digital era is important to discuss. This article aims to discuss various thoughts related to the reorientation of Islamic education in Islamic higher education in the digital era.

\section{B. Research Methods}

This article is the result of library research. Primary data is taken from the latest published journals and can be accessed online. The discussion is focused on approaches, models, and methods in Islamic studies using descriptive analysis that was associated with issues of social development.

\section{Results and Discussion}

To sharpen the results and discussion, some definitions and discussions will be elaborated on the digital era and Islamic education. Furthermore, a discussion about the reorientation of Islamic education in the digital era can be conducted. In the final section, a number of recommendations were made for stakeholders so that the reorientation of Islamic higher education institutions can run as expected.

\section{Digital era}

The digital age is a phrase that comes from two words, era and digital. According to the onlineIndonesian Dictionary (KBBI), the word era includes a type of noun which means a period of time in history, a number of years in the period of time between several important events in history, time. While the word digital is an adverb related to numbers for a particular calculation system, related to numbering ${ }^{6}$. Other sources say that the word digital comes from Greek 'digitus' which means fingers. The normal number of human fingers is ten (10). The number ten consists of two radices, namely 1 and 0 so that digital describes the state of a number

${ }^{4}$ H.A.R Tilaar, Beberapa Agenda Reformasi Islam DalamPerspektif Abad 21 (Magelang: Tera Indonesia, 1998).

5IrjaPratama Putra and Zulhijra, "Reformasi Pendidikan Islam Di Indonesia," Jurnal PAI Raden Fatah 1, no. 1 (2019): 117-27.

${ }^{6}$ Pusat Bahasa Kemdikbud, "KamusBesar Bahasa Indonesia (KBBI) Versi Online," accessed June 27, 2019, https://kbbi.web.id/digital. 
consisting of numbers 0 and 1, meaning off and on (binary numbers). All computer systems using the database are also referred to as Bit (Binary Digit $)^{7}$. Therefore, the digital era can be interpreted as the era of computerization, in which all human activities can be socialized with a medium of computer technology (multi-screen), with various representations, forms, numerical, and varied narrative models 8 .

The digital era demands learning to reform into digital learning. This learning can be a solution to various problems in learning, which can be initiated from reforming the way conventional delivery of learning (manual) becomes a way of delivering contemporary (digital) learning ${ }^{9}$. 'Digital' is the latest descriptive term used in education to express the incorporation of learning activities into new information and communication media ${ }^{10}$. 'Computer-based' has been used primarily to characterize types of learning material, 'digital' is now rhetorically constitutive from all institutions (the digital university) ${ }^{11}$, andof course from all eras (the digital era) ${ }^{12}$, as well as the digital world (a digital world $)^{13}$.

\section{Islamic Education}

Although there is no absolute agreement on the limits of Islamic education, Irja Putra Pratama and Zulhijra, provided conclusions that what is meant by the definition of Islamic education can be viewed from things, namely institutionally and substantively. Institutionally, Islamic education is educational institutions under the auspices of the Ministry of Religion, namely the Directorate General of Islamic Education (DirjenPendis) which includes the Directorate of Islamic Higher Education (Dit-PTKI), Directorate of Madrasa (Dit-Madrasah), and Directorate Early Education

${ }^{7}$ Meilani, "BerbudayaMelalui Media Digital," JurnalHumaniora 5, no. 2 (2014).

${ }^{8}$ Wahyu Budiyantoro, "Dakwah Di Era Digital," KOMUNIKA 11, no. 2 (2017): 263-81.

${ }^{9}$ Bryan C.Hassle et al., Education Reform for the Digital Era, ed. Jr. and Daniela R. Fairchild Chester E.Finn (Washington, D.C: Thomas B. Fordham Institute, 2012).

${ }^{10}$ Robin Goodfellow, "Literacy, Literacies and the Digital in Higher Education," Teaching in Higher Education 16, no. 1 (2011): 131-44, https://doi.org/10.1080/13562517.2011.544125.

${ }^{11}$ Reza Hazemi, stephenhailes, and stevenwibur, The Digital University: Reinventing the Academy (London: Springer Verlag, 1998).

${ }^{12}$ christineborgman, Scholarship in the Digital Era (Cambs: MA: MIT Press, 2007).

13betty collis, Tele-Learning in a Digital World: The Futute of Distance Learning (London: International Thomson, 1996). 
and Islamic Boarding School (Dit-PD Pontren). Substantively, Islamic education is an educational institution that transforms knowledge while transforming the values of Islamic teachings to form a balanced human being between intellectual, emotional, and spiritual. It was this employee who was expected to be able to answer the challenges of the times ${ }^{14}$.

In terms of terminology, there are two meanings of Islamic education, namely education about Islam which views Islam as subject matter, and education according to Islam which places Islam as a perspective in education. If Islam is only seen as a subject matter, the process that occurs is the transfer of Islamic values from the older generation to the younger generation without creating a creative and progressive thinking condition for students. Islam that is understood as a perspective in Islamic education will view Islam as a set of valuesthat are part of the education system, which means concepts about education. ${ }^{15}$ The functional purpose of Islamic education is the potential of human essence which consists of faith/belief, science, morality and experience. ${ }^{16}$

There are 13 issues of Islamic education that have been summarized by Irja Putra Pratama and Zulhijra17 including, 1) the use of classical Islamic thought so that Islamic material is placed on curricula that provide opportunities for creativity and the development of thinking 18 ; 2) systematics of the department in ICM lacks a theoretical basis and relevance to the objective world of the people; 3) the existence of a conceptual crisis regarding the definition or limitation of the sciences in the Islamic education system, namely the division of the sciences in Islam that are separate between profane sciences (worldly sciences) and the sacred sciences (religious sciences); 4 ) the institutional dichotomy between general education and religious education; 5) the methodological and pedagogical crises that prioritize the teaching process rather than the educational process so that it only fills the cognitive aspects but neglects personal/character formation, even though people with strong character can survive in the era of postmodernism as it is today; 6) the crisis orientation that is more oriented to the past so that it is unable to face future challenges; 7 ) the less dependable pattern of education outlined by

14Pratama Putra and Zulhijra, "Reformasi Pendidikan Islam Di Indonesia."

${ }^{15}$ Muhammad Djazaman, "Konsep Pendidikan Islam,"," Jurnalllmu Pendidikan Islam 1 (90): 2009.

${ }^{16}$ SigitPriatmoko, "MemperkuatEksistensi Pendidikan Islam Di Era 4.0," TA'LIM: JurnalStudi Pendidikan Islamndidikan Islam 1, no. 2 (2018): 1-19.

17Pratama Putra and Zulhijra, "Reformasi Pendidikan Islam Di Indonesia."

${ }^{18}$ MuslihUsa, Pendidikan Islam Di Indonesia: Antara Cita Dan Fakta (Yogyakarta: PT. Tiara Wacana, 1991). 
the government; 8) the lack of funds so that orientation is dictated by institutions that determine employment; 9) the unstable national education system; 10) the rapid development of culture and changes in society; 11) lack of public appreciation and psychological barriers that originate from the powerlessness of Islamic education in fulfilling the logic of competition; 12) the existence of materialistic social layers without regard to ideological aspects in choosing educational institutions; and 13) the tendency of mismanagement in Islamic education itself.

The problems in Islamic education enliven the argument about the urgency of the reorientation of Islamic education in the digital era. There needs to be proper reorientation so that these problems can be handled properly. Thus, the profile of human beings can be more approached through Islamic education so that the development of technology and social media are also brought along without any worries andthey can be utilized to improve the quality of faith reflected in the social-public piety. The description of the reorientation of Islamic education in the digital era in question will be described below.

\section{Islamic Education in the Digital Age}

The lag of Islamic education caused by various problems as described earlier is also caused by latent problems that never end. According to $\operatorname{Rosidin}^{19}$, there are four factors that cause Islamic education to often get sharp criticism so that reorientation needs to be done immediately. First, there is a cultural gap where there is an imbalance between the speed of science and technology development and the speed of development of education so that Islamic education is less responsive to the dynamics of social change and makes it less contextual. Second, the second class stigma that places Islamic education after general education. This is evidenced by Webometrics' top 10 ranking data which are occupied by PTU (higher education institutions). ${ }^{20}$ Third, there is a dichotomization of knowledge despite integration efforts, but it has not shown significant results. Fourth, there is a political dualism between the Ministry of Religion and the Ministry of Education and Culture and the Ministry of Research and Technology concerning issues of salary, certification and incentives for educators and other issues concerning education management policies. ${ }^{21}$

${ }^{19}$ Rosidin, "Problematika Pendidikan Islam PerspektifMaqasidShari'ah," Maraji': JurnalStudiKeislaman 3, no. 1 (2016): 186.

20"Rangking Web of Universities ,Januari 2018," accessed July 20, 2018, http://www.webomatrics.info/en/Asia/indnesia.

21Priatmoko, "MemperkuatEksistensi Pendidikan Islam Di Era 4.0." 
In welcoming Islamic education 4.0 the latent problems need to be solved, namely through the reorientation of Islamic education in the digital era. The reorientation of Islamic education in the digital era requires at least three things, namely the reorientation of approaches, models, and methods simultaneously. The results of studies on various literature indicate that the reorientation of Islamic education in the digital era can be done through a historical approach, using a true diversification model of education, and blended learning methods. Discussions about the three in the reorientation of Islamic education, especially in Islamic higher education institutions, are described in the following sub-sections.

\section{Approach: Historical Approach}

The approach that is necessarily used in the reorientation of Islamic education is the historical approach. According to NasitotulJanah, Islam as a view of life is always confronted with the progressivity of life's problems which is able to accommodate the various changes that have taken place, so the normative and historical approaches in Islamic studies have different implications.Normative approach is still focused on normative values and rigid text sacredness so that Islamic scholarship becomes repetitive and involute, in which it is often paradoxical to humanitarian problems. Whereas the historical approach focuses more on the substantial meaning behind religious symbols and texts so that it is more progressive and compatible with. 22

According to Amin Abdullah, the approach and understanding of the theological normative-textual and historically-critical religious phenomena is often tinged with constructive and destructive tensions. The first group alleges that the second group had a reductionist understanding of religion. Whereas the second group claims that the first group only absolutes the text without trying to understand its psychological and sociologicalbackgrounds. Therefore, the most serious problem for Muslims is how to associate fundamental and absolute normativity values with historicity and the historical context of life that has always undergone a change in civilization ${ }^{23}$. The reorientation of Islamic education in the digital era can be one of the alternative solutions offered for this problem.

${ }^{22}$ NasitotulJanah, "PendekatanNormativitas Dan Historisitas Serta ImplikasinyaDalamPerkembanganPemikiran Islam," Cakrawala: JurnalStudi Islam 13, no. 2 (2019): 102-119.

${ }^{23}$ Amin Abdullah, Studi Agama NormativitasAtauHistorisitas (Yogyakarta: PustakaPelajar, 2004). 
If these fundamental problems are related to the conditions of thought, law, and education in the culture of contemporary Muslim society, then now is the right time to start daring to think again about the thoughts and practices of religious and Islamic education by using creative imagination in the learning and lecturing process. Islamic religious sciences in the present era, such as fiqh, kalam/aqeedah/tawhid, worship, interpretation, hadith, date, morality, should no longer be sterile from encounters and struggles with other scientific disciplines outside of themselves. Islamic education in particular and religion in general can no longer be conveyed to students in their isolation and closure from input from other disciplines and vice versa. Educators need to think creatively and have a creative imagination, dare to associate, have dialogue with a description in one field of religious science in relation to, have discussion and encounter with other scientific disciplines. If this step is not carried out, then religious studies in schools, especially lectures in higher education,will be at risk of losing relevance to the problems of the lives of surrounding communities which are certainly more complex ${ }^{24}$ Amin Abdullah calls this idea a paradigm of integration-interconnection with the theory of spider webs. ${ }^{25}$

The digital era and the rapid, infinite information are a big challenge for the world of education to respond by taking as many opportunities as possible and warding off the slightest threat. One of the major contributions that can be contributed by the world of education is the ability to filter cultural valuesso that the nation's morality is maintained. The role of Islamic education in this realm can be done by revitalizing the Qur'anic values. According to Siswanto and YuliAnisyah, there are three dimensions that need to be fostered and developed including spiritual dimensions, cultural dimensions, and cultural dimensions. The spiritual dimensions of faith, piety, and noble character are reflected in worship and muamalah. The cultural dimension is a solid and independent personality, social and national responsibility. The dimensions of intelligence are intelligent, creative, skilled, discipline, work ethic, professional, innovative and productive ${ }^{26}$. These three dimensions can be realized through the historical approach and the integration-interconnection paradigm as discussed in the previous paragraphs. In Islamic studies, an integrative

${ }^{24}$ Abdullah, "RELIGION, SCIENCE AND CULTURE An Integrated , Interconnected Paradigm of Science 1."

${ }^{25}$ Amin Abdullah, Islamic Studies DalamParadigmaIntegrasi-Interkoneksi (SebuahAnalogi) (Yogyakarta: SUKA Press, 2007).

${ }^{26}$ SiswantoSiswanto and YuliAnisyah, "Revitalisasi Nilai-Nilai Qur' AniDalam Pendidikan Islam Era RevolusiIndustri 4.0," Islamuna: JurnalStudi Islam 5, no. 2 (2019): 139, https://doi.org/10.19105/islamuna.v5i2.2076. 
approach is a study that uses integrated perspectives and or methods of analysis, consisting of two analyzes, integrative between all texts related (nash) and the theme being discussed, and integrative between texts (nash) with other sciences. ${ }^{27}$

\section{Model: True Diversification}

The model referred to in this study is a model of Islamic education institutions. In the process of empowering the ummah, there is still a debate about the model of a proper Islamic education institution because it is related to the tasks and cultural-educational responsibilities of the community. According to Jusuf Amir Faesal, the development of Islamic education institutions implicitly shows an accentuated shift from meritocratic education formulation. ${ }^{28}$

There are two types of diversification of Islamic education institutions. First, true diversification with clear goals and directed at professional differentiation. This diversification of the first type of educational institution is a good, effective and efficient way. Second, pseudo diversification is only in the form of birth, in which there are no clear and directed goals, far from professional differentiation. This second type will have an impact on scattering, duplication and ineffectiveness. ${ }^{29}$ According to Muslim Usa, there are two types of Islamic education with a true diversification model, namely Islamic boarding schools and madrasa. Islamic boarding schools are non-formal educational institutions, while madrasa is formal education under the Ministry of Religion. ${ }^{30}$ Islamic higher education (DIKTIS) is the highest level of formal Islamic education under the Ministry of Religion, a continuation of the madrasa. Therefore, this study focuses on the discussion of the importance of reorientation of Islamic education in Islamic higher education (DIKTIS) with the implementation of the tridharma to be more comprehensive in contributing to the community.

The Tridharma of higher education hereinafter referred to as Tridharma, is the obligation of universities to organize education, research, and

${ }^{27} \mathrm{Fu}^{\prime}$ adArif Noor, "PendekatanIntegratifDalamStudi Islam," Cakrawala 1 (2018): 60., https:/ / doi.org/10.31603/cakrawala.v13i1.2043.

${ }^{28}$ Jusuf Faesal Amin, Reorientasi Pendidikan Islam (Jakarta: GemaInsani Press, 1995).

${ }^{29}$ Binti Maunah, "Lembaga Pendidikan Islam Di Indonesia: Kajian DeskripsiAnalitik Model Lembaga Pendidikan Islam," Empirisma 24, no. 2 (2015): 264-271.

30Usa, Pendidikan Islam Di Indonesia: Antara Cita Dan Fakta. 
community service ${ }^{31}$. Islamic higher education (DIKTIS) has the same obligation as higher education (DIKTI) in implementing tridharma. However, the implementation of tridharma in Islamic higher education (DIKTIS) needs to be adjusted to its distinction as an organizer of higher education that is Islamic in nature. Education, research, and community service in Islamic higher education (DIKTIS) are carried out with the Islamic paradigm.

The changing times in the form of the digital era and the era of industrial revolution 4.0 represent opportunities and challenges for Islamic higher education (DIKTIS) to do reorientation. The technical implementation of reorientation can be done through tridharma, namely education, research, and community service. Research and development that produces article products, teaching materials, learning media, and learning technology can be disseminated through education and community service. Thus the profile of the insankamil community (imanIslam-ihsan) will be realized.

\section{Method: Blended e-Learning}

The reorientation of Islamic education in the digital era is increasingly needed with the emergence of the 4.0 industrial revolution era, an era marked by the increasingly central role of cyber technology in human life. The emergence of the term 4.0 education is one response to this. Education 4.0 integrates cyber technology in learning, including meetings between uilmuu nerves, psychology, cognitive, and educational technology. Blended learning is the right method used in the reorientation of Islamic education.

Blended learning has been defined in Cisco Systems as a combination of traditional learning and e-learning. The aspects of e-learning such as web-based instruction, video streaming, audio, synchronous, and asynchronous are integrated into typical traditional learning face-to-face. Blended e-learning can be followed by students with various cultures and the ability to choose the format offered in the learning material. There are two types of blended learning. First, learning that combines traditional classes and e-learning. This type is best known because it appears to combine theory and practice in combining teacher-student and studentcentered learning. Second, synchronous and asynchronous mixing in elearning technology. This second type is very useful to be used as a

${ }^{31}$ PresidenRepublik Indonesia, "Undang-UndangRepublik Indonesia Nomor 12 Tahun 2012 Tentang Pendidikan Tinggi" (2012). 
solution to the many international students with different cultures and geographical locations. ${ }^{32}$

The Indonesian government has collaborated with Cisco in an effort to accelerate the digitalization of five main areas, namely digital government, digital industry, digital state-owned enterprises (BUMN), cyber security and digital inclusion. ${ }^{33}$ This shows that the acceleration has not touched much on the education aspect. Therefore, the world of education must be proactive in producing digital learning products and technology. Based on the four latent issues of Islamic education that have been discussed previously, in this case PTKI requires a more systematic and serious effort compared to PTU.

\section{CONCLUSION}

Islamic education in the digital era needs to place Islam not only as a subject matter but rather in Islam as a perspective in education. This article recommends the reorientation of Islamic education in the digital age can be done through a historical approach, avoiding pseudo-diversification models, and using Blended e-learning methods. Thus Islamic education can carry out roles and functions in education that is sensitive to the times and at the same time the manifestation of Islam rahmatanlil'alamin[.]

\section{REFERENCES}

Abdullah, Amin. Islamic Studies DalamParadigmaIntegrasi-Interkoneksi (SebuahAnalogi). Yogyakarta: SUKA Press, 2007.

-- - Studi Agama NormativitasAtauHistorisitas. Yogyakarta: PustakaPelajar, 2004.

Abdullah, Amin. Studi Agama NormativitasAtauHistorisitas. Yogyakarta: PustakaPelajar, 2004.

Abdullah, $\mathrm{M}$ Amin. "RELIGION , SCIENCE AND CULTURE An Integrated , Interconnected Paradigm of Science 1" 52, no. 1 (2014): 175-203. https:// doi.org/10.14421/ajis.2014.521.175-203.

${ }^{32}$ Ahmed Al-Hunaiyyan, "Blended E-Learning Design: Discussion of Cultural Issues," International Journal of Cyber Society and Education 1, no. 1 (2008): 17-32.

${ }^{33}$ MohKhoiryAlfarizi, "Indonesia

Gandeng

Cisco UntukPercepatanDigitalisasi," 2018, https:/ / tekno.tempo.co/read/1127391/indonesia-gandeng-cisco-untukpercepatan-digitalisasi $/$ full\&view $=$ ok. 
Ahmed Al-Hunaiyyan. "Blended E-Learning Design: Discussion of Cultural Issues." International Journal of Cyber Society and Education 1, no. 1 (2008): 17-32.

Amin Abdullah. Islamic Studies DalamParadigmaIntegrasi-Interkoneksi (SebuahAnalogi). Yogyakarta: SUKA Press, 2007.

Binti Maunah. "Lembaga Pendidikan Islam Di Indonesia: Kajian DeskripsiAnalitik Model Lembaga Pendidikan Islam." Empirisma 24, no. 2 (2015): 264-271.

borgman, christine. Scholarship in the Digital Era. Cambs: MA: MIT Press, 2007.

Budiyantoro, Wahyu. "Dakwah Di Era Digital." KOMUNIKA 11, no. 2 (2017): 263-81.

Burhan, Hasnidar. "Era Digital, Kurikulum PT Dirombak." Nasional.Sindonews.Com, 2018.

C.Hassle, Bryan, Emily Ayscue Hassle, Frederick M.Hess, Tamara BulterBattaglino, Matt Haldemen, Eleanor Laurans, Paul T.Hill, and John E.Chubb. Education Reform for the Digital Era. Edited by Jr. and Daniela R. Fairchild Chester E.Finn. Washington, D.C: Thomas B. Fordham Institute, 2012.

collis, betty. Tele-Learning in a Digital World: The Futute of Distance Learning. London: International Thomson, 1996.

Fu'adArif Noor. "PendekatanIntegratifDalamStudi Islam." Cakrawala 1 (2018): 60. https://doi.org/10.31603/cakrawala.v13i1.2043.

Goodfellow, Robin. "Literacy, Literacies and the Digital in Higher Education." Teaching in Higher Education 16, no. 1 (2011): 131-44. https://doi.org/10.1080/13562517.2011.544125.

Hazemi, Reza, stephenhailes, and stevenwibur. The Digital University: Reinventing the Academy. London: Springer Verlag, 1998.

Jusuf Faesal Amin. Reorientasi Pendidikan Islam. Jakarta: GemaInsani Press, 1995.

Kemdikbud, Pusat Bahasa. "KamusBesar Bahasa Indonesia (KBBI) Versi Online." Accessed June 27, 2019. https://kbbi.web.id/ digital.

Meilani. "BerbudayaMelalui Media Digital." JurnalHumaniora 5, no. 2 (2014).

MohKhoiryAlfarizi. "Indonesia Gandeng Cisco UntukPercepatanDigitalisasi," 2018. https:/ / tekno.tempo.co/read/1127391/indonesia-gandeng-ciscountuk-percepatan-digitalisasi $/$ full\&view $=$ ok.

Muhammad Djazaman. "Konsep Pendidikan Islam,"." JurnalIlmu Pendidikan Islam 1 (90): 2009. 
NasitotulJanah. "PendekatanNormativitas Dan Historisitas Serta ImplikasinyaDalamPerkembanganPemikiran Islam." Cakrawala: JurnalStudi Islam 13, no. 2 (2019): 102-119.

Pratama Putra, Irja, and Zulhijra. "Reformasi Pendidikan Islam Di Indonesia." Jurnal PAI Raden Fatah 1, no. 1 (2019): 117-27.

Priatmoko, Sigit. "MemperkuatEksistensi Pendidikan Islam Di Era 4.0." TA'LIM: JurnalStudi Pendidikan Islamndidikan Islam 1, no. 2 (2018): 1-19.

“Rangking Web of Universities ,Januari 2018." Accessed July 20, 2018. http://www.webomatrics.info/en/Asia/indnesia.

Republik Indonesia, Presiden. Undang-undangRepublik Indonesia Nomor 12 Tahun 2012 tentang Pendidikan Tinggi (2012).

Rosidin. "Problematika Pendidikan Islam PerspektifMaqasidShari'ah." Maraji': JurnalStudiKeislaman 3, no. 1 (2016): 186.

Salim, Arskal. "Welcome to AICIS 2019 Digital Islam Education Youth," 2019. http://diktis.kemenag.go.id/aicis/index.php/home/.

Siswanto, Siswanto, and YuliAnisyah. "Revitalisasi Nilai-Nilai Qur'AniDalam Pendidikan Islam Era RevolusiIndustri 4.0." Islamuna: $\begin{array}{llllll}\text { JurnalStudi Islam 5, no. } 2019): & 2 & \text { (2019. }\end{array}$ https://doi.org/10.19105/islamuna.v5i2.2076.

Tilaar, H.A.R. Beberapa Agenda Reformasi Islam DalamPerspektif Abad 21. Magelang: Tera Indonesia, 1998.

Usa, Muslih. Pendidikan Islam Di Indonesia: Antara Cita Dan Fakta. Yogyakarta: PT. Tiara Wacana, 1991. 
164 | AKADEMIKA, Vol. 24, No. 01 January - June 2019 